\title{
Fatwas of the Indonesian council of ulama and its contributions to the development of contemporary Islamic law in Indonesia
}

\author{
La Jamaa
}

State Institute of Islamic Studies (IAIN) Ambon

E-mail:lajamaa26@gmail.com

DOI: 10.18326/ijims.v8i1.29-56

\begin{abstract}
This article addresses the contributions of the fatwas of the Indonesian Council of Ulama (MUI) to the transformation of contemporary Islamic law and the development of Islamic law in Indonesia, from 1975 to 2011. It aims to respond to the existing papers claiming that the MUI's fatwas were likely to be compliant with the government's wishes and dependent. This paper also wants to demonstrate another fact that the MUI has been inconsistently using their own guidelines for the determination of its fatwas. The present study found that over 26 years the MUI's fatwas contributed positively to the transformation of contemporary Islamic law in Indonesia. During the period, the MUI produced 137 fatwas and 50 decisions, either addressed to Muslims and the Indonesian government. Therefore, the MUI's fatwas, as among the elements of Islamic law in Indonesia, also contributed to the development of contemporary Islamic law in Indonesia.
\end{abstract}

Artikel ini mengkaji kontribusi fatwa Majelis Ulama Indonesia terhadap transformasi hukum Islam kontemporer, dan perkembangan hukum Islam di 
Indonesia, dalam kurun waktu 1975 sampai dengan 2011. Tulisan ini bertujuan untuk menanggapi tulisan yang telah ada selama ini, bahwa fatwa MUI cenderung mengikuti keinginan pemerintah, dan tidak mandiri. Tulisan ini juga ingin membuktikan fakta lain, bahwa MUI tidak konsisten menggunakan pedoman penetapan fatwanya. Penelitian ini menemukan, bahwa fatwa MUI selama kurun waktu 26 tahun, telah memberikan kontribusi positif terhadap transformasi hukum Islam kontemporer di Indonesia. Selama kurun waktu tersebut, MUI telah menghasilkan 137 fatwa, dan 50 keputusan baik yang ditujukan kepada umat Islam, maupun pemerintah Indonesia. Sehingga fatwa MUI, sebagai salah satu unsur hukum Islam di Indonesia, telah juga memberikan kontribusi terhadap perkembangan hukum Islam kontemporer di Indonesia

Keywords: Fatwa; MUI; Contemporary Islamic law; Islamic law in Indonesia

\section{Introduction}

The advancement of civilization spawn by the progress of science and technology produces problems of contemporary Islamic law in Indonesia, requiring ijtihad ${ }^{1}$ by the ulamas in Indonesia. This is due to the fact that the advancement of science and technology spawns humanity dilemmas, especially with regard to the legal and moral aspects. Abortion, sterilization, corneal transplantation, heart valves, replacement surgery, genital enhancement, artificial insemination, human cloning, breast milk banks, sperm banks, eye banks and other organ banks, autopsy, preservation of bodies for research purposes, organ transplantation,

${ }^{1}$ Etymologically, Ijtihàd is derived from the verb jahada, meaning "devoting all the ability of the reason to solve a complicated problem". See Muhammad Musa Towana, Al-Ijtihād: Mādha Hạjatinā Ilaihi fĩ Hädha al-Aṣr, n.p: Dār al-Kutub al-Hadisah, 1972, 97. Terminologically, ijtihàd is devotion of the intellectuality of Islamic jurists or mujtahids to formulate or discover Islamic law. See Muhammad Khudari Bik, Ușul al-Fiqh, Beirut: Dar al-Fikr, 1981, 367. Thus, ijtihad is the ability to develop Islamic legal reasoning. See M. Cherif Bassiouni, "Sources of Islamic Law, and the Protection of Human Rights in the Islamic Criminal Justice System," in The Islamic Criminal Justice System, New York: Oceana Publications, Inc., 1982, 16. 
anti-menstrual pills, use of human organs, placenta and urine for drugs and cosmetics, civet coffee, use of meningitis vaccine, formalin and others, on the one hand, provide benefits to human beings but, on the other hand, poses challenges from Islamic law aspects.

According to Islamic law, science and technology are not value-free, so that they should be given values according to Islamic law in order to prevent from deviation. Obviously, the use of science and technology is not only based on the principle of benefit for humanity, but it must also be adjusted to and not violate the divine values. This is because Islamic law combines the divine value, deriving from a transcendent God entitled to set the way of life for mankind, ${ }^{2}$ with human values, since Islamic law always pays attention to human needs in profane life.

This shows that the products of modern technology should be able to combine the value of obedience to Allah (sacred spiritual values) with the worldly needs (profane human values). The considerations of worldly needs (human dimension) should not ignore and outdo the divine dimension with regard to using the products of science and technology. In this context, the fatwas of the MUI are highly urgent for Indonesian Muslims in order for the products of modern technology to be synergized with the rules of Islamic law. Hence, the products of science and technology can be in line with tauhid, faith and piety to Allah.

In line with the foregoing, Indonesian ulamas, who are members of the organization of the Indonesian Council of Ulama (MUI), have transformed Islamic law in the form of quite diverse fatwas. The diversity derives from the variety of problems appearing within the Indonesian society. The MUI, as a legal study and fatwa-giving institution, continues to adhere to the spirit of giving birth to legal ideas and other religious

${ }^{2}$ Abdur Rahman I. Doi, Shari'ah The Islamic Law, trans. Basri Iba Asghary and Wadi Masturi, Shari'ah Kodifikasi Hukum Islam, Jakarta: PT Rineka Cipta, 1993, 1. 
IJIMS: Indonesian Journal of Islam and Muslim Societies, Volume 8, Number 1, June 2018: 29-56

aspects in accordance with the teachings of the Quran and hadith in performing its functions. ${ }^{3}$

The fatwas of MUI, as with other fatwas in general, are case-specific since they represents responses to questions asked by those requesting fatwas, either the public or the government. The fatwas of MUI are also likely to be dynamic since they are responses to new developments encountered by the public, despite the fact that the contents of the fatwa itself are not necessarily dynamic. ${ }^{4}$

The dynamism of the MUI's fatwas is demonstrated by Hamka's views (the General Chairman of the MUI of 1975-1981 period) on dynamic Islamic law and positioning the second caliph, Umar bin Khattab, as a good example of a Muslim with regard to understanding the spirit of Islamic law (ruh al-syari'ah). ${ }^{5}$ However, the MUI's fatwas are considered less dynamic by some Islamic scholars. For example, in terms of gender, it is considered less sensitive to gender equality and women's rights; ${ }^{6}$ even in terms of aqidah, the MUI's fatwas are perceived as anti-pluralism, ${ }^{7}$ which, according to Gillespie, ${ }^{8}$ caused controversies.

${ }^{3}$ See M. Hasbi Umar, Nalar Fiqih Kontemporer, Jakarta: Gaung Persada Press, 2007, 24.

${ }^{4}$ Muhammad Atho Mudzhar, "Pengaruh Faktor Sosial Budaya Terhadap Pemikiran Hukum Islam,” in Cik Hasan Basri (ed.), Hukum Islam dalam Tatanan Masyarakat Indonesia, Jakarta: Logos Wacana Ilmu, 1998, 3.

${ }^{5}$ See Mohammad Atho Mudzhar, Fatwas of The Council of Indonesian Ulama: A Study of Islamic Legal Thought in Indonesia 1975-1988, Jakarta: INIS, 1993, 56.

${ }^{6}$ See Siti Musdah Mulia, Muslimah Reformis Perempuan Pembaru Keagamaan, Bandung: Mizan, 2005, 124.

7 See Syafiq Hasyim, "Majelis Ulama Indonesia and Pluralism in Indonesia," Sage Journals: Philosophy $\mathcal{E}$ Social Critism, Januari 2015. See also Syafiq Hasyim, "The Council of Indonesian Ulama (Majelis Ulama Indonesia, MUI) and Religious Freedoom," IRASEC, (December 2011). See also Khoiruddin Nasution, "Fatwa Majelis Ulama Indonesia (MUI): On Ahmadiyah," Millah, vol. 7, no. 2, (2008); M. Hilaly Basya, "The Concept of Religious Pluralism in Indonesia: a Study of the MUI's Fatwa and the Debate among Muslim Scholars", Indonesian Journal of Islam and Muslim Societies, vol. 1, no. 1 (June 2011), 69-93.

${ }^{8}$ See Piers Gillespie, "Current Issues in Indonesian Islam: Analysing the 2005 Council of Indonesian Ulama Fatwa No. 7 Opposing Pluralism,” Journal of Islamic Studies, vol. 18, 
Regardless of whether it is dynamic or not, the MUI has produced numerous fatwas. According to Mudzhar's study of the MUI's fatwas between 1976 and 1988, the MUI produced 39 fatwas. In that period, the MUI seemed to restrict the giving of fatwas for the government's questions and only provided "letters of advice". ${ }^{9}$ Additionally, Ikhwan also argues the same. ${ }^{10}$ Furthermore, Mulia's study indicated that during the 1975-1997 periods, the MUI produced 76 fatwas. The majority of those fatwas highlighted the societal or contemporary Islamic legal problems. ${ }^{11}$ It was strongly supported by the MUI's human resources, deriving from the representatives of traditional and modern ulama groups. ${ }^{12}$

In this regard, the fatwas of the MUI constitute an attempt to transform Islamic law in the contemporary era experienced by Muslims and the Indonesian nation. This paper will examine the contribution of the MUI's fatwas to the transformation of contemporary Islamic law and the development of Islamic law in Indonesia during the 1975-2011 period.

\section{Duties and functions of the fatwa commission of the Indonesian council of ulama (MUI)}

Ulamas have a crucial role in the social life of Indonesian society since they are decisive figures for the survival of Muslims and are the spearhead for Muslims in solving various problems, either in relation to the government, state institutions, intellectuals, and the general public. In terms of morality and intellectuality, ulamas are responsible for change and the social and religious development of Muslims. Ulamas moral responsibility

no. 2 (2007), 202.

${ }^{9}$ See Mohammad Atho Mudzhar, Fatwas of the Council of Indonesian Ulama..., 72-75.

${ }^{10}$ See Moch. Nur Ikhwan, "'Ulama, State, and Politics: Majelis Ulama Indonesia After Soeharto,"Islamic Law and Society, vol. 12, no. 1 (2005).

${ }^{11}$ See Siti Musda Mulia, Muslimah Reformis..., 126.

${ }^{12}$ See Nadirsyah Hosen, "Behind the Scenes: Fatwas of Majelis Ulama Indonesia (19751998), Journal of Islamic Studies, vol. 15, issue 2 (2004), 147. 
is a consequence of their status as the heir to the prophet, being tasked to develop the teachings of Allah on the earth, while the intellectual responsibility is among the human dimensions which is important to instill and develop Islamic teachings rationally, objectively, and understandable to the public. ${ }^{13}$

Obviously, with regard to the implementation of Islamic law, ulamas and Muslim scholars play an important role to implement Islamic law Thus, Islamic law is not sufficient to reside merely in the theoretical level (law in book), but it should be able to be grounded, being in the practical level (law in action), in order to be implementable in everyday life.

In line with the foregoing, the existence of the MUI is highly strategic for the benefit of Muslims in the societal and nation context. The MUI is the advisory body "to guide the Islamic community and government." 14 Thus, the MUI is not allowed to make practical programs, on advice from the former president Soeharto at that time. In addition, the MUI also does not engage in practical political activities, which are the domain of political parties. Therefore, the MUI's Articles of Association states that the MUI performs its duties to provide fatwas and advices, both to the government and Muslims, associated with religious problems in particular, and all the problems facing the nation in general. The MUI is also expected to foster the spirit of ukhuwah (brotherhood) among Muslims, acting as Muslims in interfaith talks. According to the third MUI chairman, KH. Hasan Basri, MUI serves "as a watchdog to ensure that there will be no laws in the country that are contradictory to the teachings of Islam". 15

${ }^{13}$ See M. Hasbi Umar, Nalar Fiqih Kontemporer, Jakarta: Gaung Persada Press, 2007, 250.

${ }^{14}$ Team Lindsey (Melissa Crouch, et al.), "Monopolising Islam? The Indonesian Ulama Council and State Regulation of the "Islamic Economy," Bulletin of Indonesian Economic Studies, vol. 48, no. 2 (2012), 253.

${ }^{15}$ Mohammad Atho Mudzhar, Fatwas of the Council of Indonesian 'Ulama..., 54. 
In this regard, the MUI contributed greatly to the Islamic legal transformation and thoughts. This is in line with the MUI's task of determining the appropriate religio-legal responses to the various issues facing community members in everyday life and as part of the development and adaptation of Islamic law. ${ }^{16}$

Despite the MUI's harmonious relationship with the government on one hand, but on the other hand the MUI are always under the pressure to defend the government's policies and programs. For example, the government's intervention to the fatwa of a group of ulamas in 1971 who stated that the use of IUD contraceptives in the implementation of family planning is prohibited in Islam. However, the Indonesian Government managed to persuade those ulamas to revoke the fatwa prohibiting the use of IUDs in $1983 .{ }^{17}$ The revocation was basically not the result of the government's pressure, but it also considered the benefits to the Indonesian Muslims, keeping in mind the principles of Islamic law in its application, namely being inserted and controlled by female medical and/or paramedical personnel. In the event that the application by male medical personnel is inevitable, it must be accompanied by the husband or another woman. ${ }^{18}$

The dynamics of the MUI's fatwas that were not necessarily compliant with the government's wishes was firmly shown during the leadership of Hamka as the Chairman of MUI. Hamka rejected the government's request to revoke the MUI's fatwa banning Muslims from attending Christian Christmas ceremonies. Hamka's persistence against the will of the New Order government resulted in Hamka's resignation from the

${ }^{16}$ Piers Gillespie, "Current Issues in Indonesian Islam," Journal of Islamic Studies, vol. 18, no. 2 2007), 206.

${ }^{17}$ Mohammad Atho Mudzhar, Fatwas of the Council of Indonesian 'Ulama..., 61.

${ }^{18}$ See Ministry of Religious Affairs of the Republic of Indonesia, Himpunan Fatwa Majelis Ulama Indonesia, Jakarta: Ditjen Bimas Islam dan Penyelenggara Haji, 2003, 191. 
IJIMS: Indonesian Journal of Islam and Muslim Societies, Volume 8, Number 1, June 2018: 29-56

Chairman of the MUI. ${ }^{19}$ The pressure of the New Order government on the MUI fatwas that contradicted the government's interests was closely related to the dominance of the New Order government against Muslims at that time.

\section{Methodology of the MUI's fatwas}

The task of the MUI Fatwa commission to give fatwas represents a hard and risky job, being accounted before Allah later. Hence, a mufti (a fatwa giver) should be aware of Islamic law in depth and its guides, rather than based on certain interests or mere claims without guides. ${ }^{20}$ Thus, according to Syamsul Anwar, the Indonesian Council of Ulama (MUI) is one of the semi-official institutions in Indonesia which involves muftis collectively formulating its fatwas. ${ }^{21}$ In addition, the MUI Fatwa Commission shall be compliant with the MUI fatwa guidelines when deciding its fatwas.

The MUI fatwa guidelines are stipulated in Decree of the MUI No. U-596/MUI/X/1997. The decree contains 3 main parts with regard to fatwa stipulation: general basis of fatwa stipulation, fatwa stipulation procedures, and technique and authority of the organization to stipulate fatwas. The general principles of the MUI's fatwa stipulation are stipulated in paragraphs 1 to 4 of Article 2. Paragraph 1 states: any fatwa must be based on Quran and the Prophet's Sunnah, and mu'tabarah guides, and is not contrary to the common good. Paragraph 2 stipulates: in the event that those bases are not contained in the Quran and Sunnah as defined in paragraph 1 of Article 2, the fatwa decided should not conflict with ijma, mu'tabar qiyas, and other legal guides, such as Istihsan, Maslahah

\footnotetext{
${ }^{19}$ Mohammad Atho Mudzhar, Fatwas of the Council of Indonesian 'Ulama..., 61-62.

${ }^{20}$ See Ministry of Religious Affairs of the Republic of Indonesia, Himpunan Fatwa..., vii.

21 Syamsul Anwar, "Fatwas, Purification and Dynamization: a Study of Tarjih in Muhammadiyah," Islamic Law and Society, vol. 12, no.1 (2005), 28.
} 
Mursalah, and Sadd al-Dhariah. Paragraph 3 states: prior to stipulating a fatwa, the opinions of the previous imams of madhhab should be review, both related to the legal guides and related to the guides used by those with dissenting opinions. Paragraph 4 states: the views of the relevant experts are to be considered when stipulating a fatwa. ${ }^{22}$

However, with the development of the era, the Decree of the Board of MUI number: U-596/MUI/X/1997 dated October 2, 1997 was deemed inadequate. The MUI issued new guidelines, the MUI's Guidelines and Procedures for Stipulating Fatwas dated 22 Shawwal 1424 H/ December 16, 2003, which regulates the procedures, mechanisms, and system for addressing religious issues. The general provisions of the 2003 MUI Guidelines and Procedures for Stipulating Fatwas state that fatwas are the ulamas' answers or explanations of religious issues and apply to the public. Fatwas are the MUI's fatwas on religious issues approved by members of the Commission in meetings (points 1 and 2). The general provisions contain several terms relating to the legal guides: Ijma' is the consensus of ulamas on a religious issue; Qiyas is the application of the original law to branches due to the similarity of legal 'illat; Istihsan is the application of maslahat juz'iyah when dealing with the general rules; and Istislahi/Maslahah mursalah is the benefits not supported by specific syar'i nash (points 9 to 12 ).

Chapter II of the General Basis and Nature of Fatwa states that fatwas are stipulated on the basis of the Quran, the Sunnah, ijma $\vec{a}$, Qiyas and other mu'tabar guides. Fatwas are stipulated collectively by an institution called the Fatwa Commission. Fatwa stipulation is responsive, proactive and anticipatory in nature. The methods of stipulating fatwas are regulated in Chapter III, stating that the views of the imams of madhhab and the mu'tabar ulamas with regard to the issue for which a fatwa is to

\footnotetext{
${ }^{22}$ Ministry of Religious Affairs of the Republic of Indonesia, Himpunan Fatwa..., 4-5
} 
be stipulated should be first reviewed carefully with their guides prior to stipulating a fatwa. Any issue with clear-cut laws should be addressed as it is. In the case of khilafiah among madhhabs: (a) a fatwa is stipulated on the basis of result of the search for a intersection among the views of the imams of madhhab by the method of al-jam' wa al-taufiq; and (b) in the event that the intersection is not found, a fatwa is stipulated on the basis of the result of tarjit by the method of muqaranah using the principles of Usul Fiqh Muqāran. An issue with no legal opinion among the madhhabs, a fatwa is stipulated on the basis of the results of jam'i (collective) ijtihad by the methods of bayāni, ta'lil (qiyāsī, istihsānì), istislähi, and sadd al-Dhariah. ${ }^{23}$

The MUI's fatwas are also stipulated on the basis of other mu'tabar guides, such as istihsān, mașlahah mursalah, and Saad al-Dhari'ah. The MUI's fatwas also pay attention to the maqasid al-syari'ah, namely the benefits associated with the protection of religion, soul, mind, descendants and property. Thus, any fatwa of the MUI can realize five kinds of primary benefits, both the ukhrawiyah/diniyah and worldly benefits. In this regard, in the event that the syar'iyah duniawiyah benefits are considered not beneficial by reason, the MUI would give priority to the benefits, since such benefits are generally defined by the qat'i guides. However, when there is a contradiction between the non-syar'iyah benefits and qat'i guides, the MUI shall prefer the qat'i guides since the benefits are only determined by reason, while the qat'i $i$ guides are determined by revelation. Revelation must take precedence over reason. According to the MUI, reason is Allah's creation given to humans; thus, reason is a being. Revelation is Allah's words, one of Allah's qadim attributes. This is because there is a conflict between revelation and reason, revelation must

${ }^{23}$ Secretariat of the Indonesian Council of Ulama, Himpunan Fatwa MUI Sejak 1975, Jakarta: Erlangga, 2011, 5-6. 
take precedence. ${ }^{24}$

This view of the MUI is criticized by Siti Musdah Mulia since some studies of ushul figh deduced the urgency of the principle of rationality in istinbat al-ahk $\llbracket m$. Rationality occupies the position of paramount importance in Islamic law, as shown in the rule: kullu ma hakama al-aql bi husnihi aw qubhihi hakama al-shari'ah bi wujubihi aw hurmatihi (When the mind determines that something is good or bad, then the sharia will also establish the law on such matters with compulsory or haram). ${ }^{25}$ The use of revelation and rationality will further improve the quality of the MUI's fatwas.

\section{Ijtihad in response to problems of contemporary Islamic law}

Fiqh terminologically is the knowledge of the syara' laws concerning human deeds based on detailed guides, or a collection of syara' laws concerning human deeds derived from detailed guides. ${ }^{26}$ According to Amir Syarifuddin, fiqh is the result of mujtahid reasoning of syara law formulated in the form of detailed rules. Thus, Islamic law is a set of rules based on the revelation of Allah and the Sunnah of the Messenger regarding the mukallaf human conduct recognized as valid and binding to all Muslims. ${ }^{27}$ It means that Islamic law is the result of ijtihad, both by means of the lafziyah istinbat of al-Quran and hadith and the istinbat ma'nawiyah.

The term 'contemporary' derives from the word co, meaning together, and tempo, meaning time. Thus, 'contemporary' means the present or reflects the time situation being passed. According to Kamus Besar Bahasa Indonesia (Indonesian Standard Dictionary) of the Ministry of Education and Culture of the Republic of Indonesia, contemporary means at the

\footnotetext{
${ }^{24}$ Ministry of Religious Affairs of the Republic of Indonesia, Himpunan Fatwa..., ix.

${ }^{25}$ See Siti Musdah Mulia, Muslimah Reformis..., 138

${ }^{26}$ Abd al-Wahab al-Khallaf, 'Ilm Ușul al-Fiqh, Jakarta: al-Majlis al-A'la al-Indunisi li alDa'wah al-Islamiyyah, 1972, 11.

${ }^{27}$ Amir Syarifuddin, Meretas Kebekuan Ijtihad Isu-Isu Penting Hukum Islam Kontemporer, Jakarta: Ciputat Press, 2002, 4.
} 
same time; the same period; the same time; in the present; currently. ${ }^{28}$ Thus, 'contemporary' is characterized as a dynamic period, changing from the past, and the present and in the future. In this regard, 'contemporary' is associated with the modern era.

Thus, the problems of contemporary Islamic law are part of Islamic law with regard to the activities of Muslims in the use of modern science and technology, or the problems of Islamic law in the contemporary era. Therefore, ijtihad is required. An ijtihad of contemporary Islamic law is quite possible since all activities in this world must have the basic rules of Allah. When it has not been found directly and textually in the decree of Allah, it can be traced to what is implied behind the decree of Allah. When it is not found implicitly behind the text of Allah's decree, it can certainly be found hidden in maqāid al-shari'ah. ${ }^{29}$

This is where ijtihad is important. The istinbat al-ahkam activities with regard to the various problems of contemporary Islamic law require various relevant guides, such as qiyas; maslahah mursalah; or the concept of maqasid al-syari'ah according to al- Syatibi ${ }^{30}$, or maslahah al-ammah; 'urf, and sadd al-Dhariah.

Even though an issue of Islamic law in the context of the present and locality has had a legal basis, but it potentially has shifted due to the difference in social conditions when the revelation was given or the hadith is informed by the Prophet. In this context, according Baqir Sadr, there is a great distance between the social situations at the time when the guides were revealed and the current social situation. Thus, it is frequently that the fuqaha or scholars are caught in four forms of error: subjectification,

${ }^{28}$ Ministry of Education and Culture of the Republic of Indonesia, Kamus Besar Bahasa Indonesia, Jakarta: Balai Pustaka, 2000, 522.

${ }^{29}$ See Amir Syarifuddin, Meretas Kebekuan Ijtihad..., 6.

${ }^{30}$ See Abu Ishaq al-Shatibi', al-Muwafaqat fi Ușul al-Sharîa ah, Volume 1, Chapter 2, Beirut: Dār Kutub al-'Ilmiyyah, 1424 H/2003 M. 
manipulation, justification, interpolation. ${ }^{31}$ In addition, the solution of contemporary Islamic law issues must also use interdisciplinary and multidisciplinary approaches.

\section{Contributions of the MUI's fatwas}

The fatwas of the MUI are part of the form of Islamic legal thought in Indonesia. Thus, the existence of the MUI's fatwas has urgency and positive contributions to the development of Islamic law in general and contemporary Islamic law in particular. Those MUI's fatwas can be understood as the efforts of Indonesian ulamas to respond to the challenges of modern life. ${ }^{32}$

Although the MUI's fatwas from 1975 to 2011 covers various areas of Muslim life in Indonesia, but this paper only samples some MUI's fatwa related to the problems of contemporary Islamic law in Indonesia.

\section{Family Planning}

In order to popularize the Family Planning program, the Indonesian government asked ulamas to issue a fatwa on family planning issues. The government demand was quite reasonable given the implementation of the family planning program intersected with religious teachings, especially Islamic law.

The MUI responded to the government's demand by conducting the National Conference of Ulama on Population, Health and Development in Jakarta on October 17 to 20, 1983. The main points of the MUI fatwa were:

1. Islam justifies the implementation of Family Planning devoted to maternal and child health, as well as the interests of children's education. The implementation should be on a voluntary basis and using contra-

\footnotetext{
${ }^{31}$ See Sayyid Baqir Sadr, Iqtișādunā, Beirut: Dār al-Ta’āruf, 1979, 404-415.

${ }^{32}$ Mohammad Atho Mudzhar, Fatwas of the Council of Indonesian 'Ulama..., 1,3,6.
} 
ceptives not forbidden by Islam.

2. Abortion in any form and at any term of pregnancy is forbidden by Islam since it is classified as murder. This includes the timing of menstruation by taking pills. An exception is only for the abortion to save the mother.

3. Vasectomy and tubectomy are prohibited in Islam, except in emergencies, such as to prevent the spread of infectious diseases or to save people who will undergo a vasectomy or tubectomy.

4. The use of Intra-Uterine Devices in Family Planned is justified, provided that the insertion is performed by a female physician or, in certain circumstances, by a male physician attended by another woman or the patient's husband. ${ }^{33}$

The first two points of the MUI's fatwas address novel issues, while the third and fourth points address old issues. The consent of the implementation of Family Planning in general and the prohibition against abortion $^{34}$ are new statements, which have never been declared by Indonesian ulamas. The fatwa on the prohibition of vasectomy and tubectomy is a repetition of the previous MUI's fatwa. This is cecause on July 13, 1979 the MUI issued a fatwa that both vasectomy and tubectomy are prohibited by Islam since in Indonesia the reproductive function of the individual in question cannot be restored. Vasectomy was included in the category of masail fiqhiyyah mu'ashirah on the third consensus of the MUI Fatwa Commissions of Indonesia in 2009, that the vasectomy as a contraceptives is performed by cutting the sperm duct resulting in a permanent sterility.

In addition, a recanalization effort does not guarantee the restoration of the fertility level of the individual in question and a vasectomy is de-

\footnotetext{
${ }^{33}$ See Ministry of Religious Affairs of the Republic of Indonesia, Himpunan Fatwa..., 191.

${ }^{34}$ See Mohamed Abdun Nasir and Asnawi, "The Majelis Ulama Fatwa on Abortion in Contemporary Indonesia,” The Muslim World, vol. 101, (January 2011).
} 
cided haram. The legal bases are QS al-An'ām: 151 and 137; al-Isra: 31; alShürā: 50; al-Nisā': 119 and the Prophet's hadith forbidding the transformation of Allah's creation and the rules of usūliyah: al-nahyu 'an al-syai' $i$ nahyun 'an wasa-ilihi (Prohibition against something is also a prohibition against its means); al-hukm yadūrù ma'a al-illati wujūdan 'adama (stipulation of a law depends on the presence or absence of illat) and the rules of figh: Là yunkiru taghayāru al-ahkāmi taghayur al-azminati wa al-amkinati wa al-ahwāli wa al'awa'tid (a change in laws is not denied due to changes in time, place, condition and custom). ${ }^{35}$ Thus, vasectomy is forbidden. The prohibition is excluded for a vasectomy by reason of an emergency since emergencies may allow forbidden things in Islam.

The fatwa allowing the use of IUDs represents an annulment of a fatwa issued by the MUI in 1971 by 11 prominent Indonesian ulamas, stating that the use of IUDs is prohibited by Islam. IUDs are prohibited since the insertion requires male doctors to see the aurat (body parts required by Islam to be covered) of women who are non-mahram (unmarriageable kin). ${ }^{36}$ The change in legal thought with regard to the use of IUDs is in line with the principle of fiqh, al-hukm yadüru ma'a al-illati wujūdan wa adama.

The first point of the fatwas demonstrated that the MUI seems to have contributed positively to the efforts to succeed the government program to realize the family planning program nationally. It supports and is responsible for the success of the program since there are Muslims who believe in qada and qadar, ${ }^{37}$ arguing that all human life has been determined by Allah. It is this overt attitude and stance towards qada and

${ }^{35}$ See Secretariat of the Indonesian Council of Ulama, Himpunan Fatwa MUI Sejak 1975, 898-901.

${ }^{36}$ Jeremy Menchik, The Co-Evolution Of Sacred And Secular: Islamic Law And Family Planning in Indonesia," South East Asia Research, vol. 22, no. 3 (2014), 369.

${ }^{37}$ See Harun Nasution, Teologi Islam: Aliran-Aliran Sejarah Analisa Perbandingan, Jakarta: UI Press, 1986, 32-35. 
qadar that ultimately challenges the Family Planning program, leading to the Family Planning being judged as religiously unlawful. ${ }^{38}$

The MUI's fatwas are based on an understanding of the hadith narrated by Ahmad and validated by Ibn Hibban from Anas that the Prophet said: "Marry a merciful lady and be able to give birth, for I am proud of the number of my people on the Judgment Day." 39 According to the MUI, this hadith should be seen in terms of the condition of Muslims in the era of the Prophet. According to the MUI, the Holy Prophet's suggestion means to strengthen the ranks of Muslims, which was still a few at that time. In contrast to the current condition, the number of Indonesian Muslims has been overwhelming, but remains looking weak in the eyes of the world, especially in terms of physical, economic and educational forces. ${ }^{40}$ Thus, what the Prophet wants in the hadith is the qualities of the generation of Muslims, including strong faith, diligent worship, being intelligent and skilled, being physically and mentally healthy and having strong body and soul.

The MUI's fatwa allowing family planning aimed at spacing birth is in line with the fiqh principle of "in principle all things are allowed, provided that there is no guide prohibiting it." ${ }^{41}$ This is in addition to the verses that give qarinah about the importance of doing positive efforts, which become part of Family Planning program, namely the maintenance of maternal health and safety, the maintenance of child spiritual and physical health, and the implementation of child education.

The permission of the use of contraceptives is inferred from the 'azal that some of the Prophet's companions had done. The legal fatwa regard-

\footnotetext{
${ }^{38}$ Among the notions that Family Planning is haram is the fatwa of Ulama Tarjih Muhammadiyah. See Muhammadiyah Central Board, Himpunan Putusan Majelis Tarjih Muhammadiyah, Yogyakarta: n.p., 1980, 308.

${ }^{39}$ Al-San'ani, Subul al-Salam, Juz 2, Bandung: Dahlan, n.d., 111.

${ }^{40}$ See M.Hasbi Umar, Nalar Fiqih Kontemporer, 198.

${ }^{41}$ Ibn Nujem, al-Asybah wa al-Nazair, Cairo: Mu'assasah wa Syurakah, 1968, 66.
} 
ing the use of IUD in the 1971 ulama fatwa was corrected for the guides in the 1983 MUI fatwa. The 1971 fatwa prohibits the use of IUDs since the insertion could expose female aurat and the prohibition is methodologically understood as hurrima li zatihi (prohibited for the substance). Furthermore, the line of guide must be changed since viewing female aurat is not prohibited when the viewer is her husband. Anything prohibited for prevention may be permitted if there is a necessity without any emergency (ma hurrima li sadd al-zara'i ubiha li hajah).42

This differs from the implementation of Family Planning using the method of abortion (the second fatwa) and vasectomy and tubectomy (the third fatwa), which are prohibited by Islam.

\section{Eye and Other Body Organ Bank}

Impaired function of eyes will also affect human activity, let alone its total loss of function (blind). Technological advances are able to transplant corneas and body organs from donors to recipients. However, corneal and body organ transplantation are hindered by the availability of corneas and body organs for recipients. In this regard, the idea of an eye bank emerges.

An eye bank is an institution or foundation that facilitates an individual who makes a willf and declares himself willing to have their eyeballs taken after death for the benefit of others in need. Thus, an eye bank is in charge of finding and collecting lists of people who donate their corneas used to help recipients in need of corneas because of blindness. In this regard, the Third Consensus of the Indonesian Fatwa Commission decided that:

1. The law of corneal transplantation to a person in need is permissible when it is urgently needed and no medical effort is made to cure it;

\footnotetext{
${ }^{42}$ See Mohammad Atho Muzdhar, Fatwas of the Council of Indonesian Ulama..., 110-111.
} 
2. Basically, a person does not have the right to donate his or her limbs to another person because he is not the true owner of his or her organs, but for the sake of helping others it is permissible and carried out according to the will.

3. Living people are unlawful (haram) to donate their corneas or other organs to others.

4. People may make a will to donate their corneas to others in need with the intention of tabarru' (voluntary and non-commercial principles).

5. Eye banks are allowed if the process of taking from the donor and its utilization is in accordance with the rules of sharia. ${ }^{43}$

The original law of corneal or body organ transplantation is actually haram, but the second point of the Third Consensus of the Indonesian Fatwa Commission stipulates that for the sake of helping others by donating their limbs to others is permissible and carried out according to the will. The second point clarifies the first point. Similarly, the third point stipulates the prohibition of living people to donate corneas or other organs to others. Thus, the second and third points make two positive contributions: (1) prohibition of donating organs with motivation other than helping others, such as the donors selling their organs (commercial purposes as stated by the fourth point); and (2) the permission to donate organs to help recipients and donate corneas (as per the fourth point). The fifth point contributes positively to the legal status of permitting eye banks to take from the donor and utilize in accordance with sharia rules.

The Third Consensus of the Indonesian Fatwa Commission can expand the treasury of contemporary Islamic law in Indonesia related to the practice of corneal and body organ transplantation and the mechanism of body organ and corneal harvesting in Indonesia. The permission

\footnotetext{
${ }^{43}$ See Secretariat of the Indonesian Council of Ulama, Himpunan Fatwa MUI Sejak 1975, 907-908.
} 
of the corneal and body organ removal and transplantation is medically different from the essence of breaking the corpse's bones as alluded to in the hadith. The process of taking and transplanting corneas and body organs of a corpse is done in accordance with medical standards and performed by surgeons. Thus, it is not identical with damaging the dead, while "damaging the corpse" as referred to the Prophet's hadith refers more to mutilation of the corpse.

Therefore, the recommendation of the Third Consensus of the Indonesian Fatwa Commission constitutes a strategic step towards the process of taking and transplanting corneas and body organs.

\section{Mechanical slaughter of animals}

To address issue mechanical slaughter of animals the Fatwa Commission of the MUI held a hearing on Monday, October 18, 1976. This was done in response to the public's concern that the meat sold in the market was considered haram since the slaughter was mechanical and not according to the traditional ways, such as using knivesas commonly used by people. The MUI's fatwa was issued after listening to the oral and written explanation of the management of PD Dharma Jaya ${ }^{44}$ on ways of slaughtering animals with the stunning mechanization system that:

1. the use of a stunning machine is intended to facilitate the collapse and fall of the animal to be slaughtered at the slaughterhouse and to relieve the pain of the animal and the slaughter is done with a sharp knife to break the hulqum (neck), mar'i (throat), and wadjain (the two veins) of animals slaughtered by Islamic slaughterers, by first reading basmalah.

2. the fallen animal stunned at the slaughter site when it is not slaughtered will wake up again freshly as before, and

\footnotetext{
${ }^{44}$ See Syamsul Hadi, "The Indonesian Council of Ulama," Indonesia Circle, no. 50 (Nov. 1989), 38.
} 
IJIMS: Indonesian Journal of Islam and Muslim Societies, Volume 8, Number 1, June 2018: 29-56

3. the slaughter using this system does not reduce the flow of blood, even the blood flows to a greater extent and more smoothly so that the meat is cleaner. ${ }^{45}$

The MUI Fatwa Commission had the fatwa that the mechanical slaughtering of animals by stunnering was a modernization of doing ihsan to animals slaughtered in accordance with the teachings of the Prophet and meeting the requirements of syar'i, so the law was halal (lawful). Therefore, Muslims need not doubt it. ${ }^{46}$

The hadith used as the guide of the MUI's fatwa is "Allah obliges Muslims to behave well (ihsān), when you will slaughter animals do it with affection, by first sharpening the knife to reduce the suffering of the animal." The rational arguments are that the method of slaughtering by machine fulfills the requirement of lawful slaughter according to the rules established by the companions of the Holy Prophet and the four Sunni schools, namely being performed on the hulqum (neck), mar'i (throat) and wadjain (the two veins of the occiput), and it constitutes a modernization of ways of doing ihsan to animals slaughtered according to the Prophet's advice. ${ }^{47}$ However, the fatwa does not refer to a particular figh book, although the description of the matter can be found in the fiqh books. For example, al-Nawawi in his book Minhaj al-Talibin says that the cutting of hulqum and mar'i is required, while the cutting of wadjain is only a sunnah. ${ }^{48}$ Similarly, al-Dimasyqi and al-Syarqawi share the same view with Nawawi. ${ }^{49}$

\footnotetext{
${ }^{45}$ Ministry of Religious Affairs of the Republic of Indonesia, Himpunan Fatwa..., 329.

${ }^{46}$ Ministry of Religious Affairs of the Republic of Indonesia, Himpunan Fatwa..., 329.

${ }^{47}$ Ministry of Religious Affairs of the Republic of Indonesia, Himpunan Fatwa..., 330. This hadith was narrated by Muslims from Shaddad ibn Aus. See Muslim bin Hajjaj alQusyairi, Sahih Muslim, Chapter 2, Beirut: Dar al-Fikr, 1992, 113.

${ }^{48}$ See Abu Zakariya Yahya al-Nawawi, Minhāj al-Tălibin wa 'Umdat al-Muftin, Semarang: Usaha Keluarga, n.d., 130.

${ }^{49}$ See Taqiy al-Din Abi Bakr al-Dimasyqi, Kifāyat al-Akhyar fi Hill Gayāt al--khtișār, volume 2, Indonesia: Dar Ihya' al-Kutub al-'Arabiyyah, n.d., 222. See also al-Syarqawi, al-Sharqawi 'ala
} 
Methodologically, the fatwa remains having its limitations since it is based only on one hadith and one rational reason, without pointing to any Quranic guides relating to slaughter of animals when many verses address it. This fatwa is also based solely on the spoken and written explanations from the Management of PD. Dharma Jaya on the ways of slaughtering animals with mechanized stunning system by Muslim slaughterers. ${ }^{50}$

The MUI's fatwa on mechanical slaughter of animals contributed to overcoming public concern about the lawfulness (halal) of mechanically slaughtered meat and provided legal legitimacy in the then promoted development of the economy with regard to the provision of animal meat to the consumers. ${ }^{51}$ That is why it is understandable that the MUI Fatwa Commission did not refer to the verses about animal slaughter since in this case the urgent study is the mechanism of slaughtering by using machines, which is quite different from the traditional slaughter of animals.

\section{Contributions of the MUI's fatwas to the development of Islamic law in Indonesia}

Contributions of the MUI's fatwas to the increase of Islamic law treasury in Indonesia can be analyzed from the quantity of the MUI's fatwas from 1975 to 2011. There are 137 fatwas consisting of the area of Aqeedah and Aliran Kepercayaan/sects (14 fatwas), the area of Worship (37 fatwas), the socio-cultural area (51 fatwas), and the area of food, medicine, science and technology (35 fatwas). Of the 37 fatwas in the area of worship, there are fatwas associated with science and technology, namely the anti-menstrual pills in performing the Hajj pilgrimage and complement the implementation of Ramadan fasting. Furthermore, there are the MUI's

al-Tahrir, volume 2, Singapura: al-Haramain li al-Tiba'ah wa al-Nasyar wa al-Tauzi, n.d., 459.

${ }^{50}$ M.Hasbi Umar, Nalar Fiqih Kontemporer..., 166.

${ }^{51}$ M.Hasbi Umar, Nalar Fiqih Kontemporer..., 166. 
IJIMS: Indonesian Journal of Islam and Muslim Societies, Volume 8, Number 1, June 2018: 29-56

fatwas on the Zakat for income with regard to determining the so-called "income," which shall include any such income as salary, honorarium, wages, services, etc. obtained by routine lawful means, such as that received by state officials or employees, or those of non-routine, such as that received by doctors, lawyers, consultants, and the like, as well as income earned from other free employment. The haul for a year is worth 85 grams of gold with zakat of $2.5 \% .^{52}$

In the area of worship there is also a MUI's fatwa on the use of zakat funds for investment, which stipulates that although the distribution of zakat mal should be done as soon as possible (fauriyah), both from muzak$k i$ to amil and from 'amil to mustahiq, but the distribution of zakat mal from amil to mustahiq can be delayed if the mustahiq does not exist yet, or there are greater benefits. The benefits are determined by the government by referring to the rules of benefits, so that the benefits constitute syar'iyah benefits. ${ }^{53}$ This fatwa of the MUI has a positive contribution to improving the quality of management and utilization of zakat funds in Indonesia.

In the social area there are several fatwas of the MUI relating to contemporary Islamic law, among which are the Christmas joint celebrations, massage parlors, population, health and development, displaying corpses in museums, law on enacting prophets/apostles in movies, SDSB, sharia mutual funds, gender bias, pornography and porno-action, endowment money, copyright, interest, intellectual property protection, games on media/game machines run by Members of Asosiasi Rekreasi Keluarga Indonesia, SMS prizes, autopsy, reverse verification, infotaiment and environment-friendly mining.

In the area of food, medicine, science and technology, there are some

\footnotetext{
${ }^{52}$ See Secretariat of the Indonesian Council of Ulama, Himpunan Fatwa..., 197-198.

${ }^{53}$ See Secretariat of the Indonesian Council of Ulama, Himpunan Fatwa..., 202-203.
} 
contemporary issues, including mechanical slaughter of animals, vasectomy and tubectomy, a will to grant corneas, artificial insemination, sex reassignment surgery, heart valve removal and use, cloning, use of body organs, placentas, and human urine for medicines and cosmetics, use of corpses for research purposes, and water recycling. ${ }^{54}$

Similarly, the Third Consensus of Indonesia Fatwa Commission on eye and body organs banks has a positive contribution to patients with blindness that cannot be medically treated, so that corneal transplantation is the last resort. Thus, the Third Consensus of Indonesian Fatwa Commission provided legal certainty about the legality of corneal transplantation practice. The condition becomes rukhsah (dispensation of permission), that is performing actions originally prohibited by the sharia according to the fiqh rule: al-darürat tubihu al-mahzurat (dangers allows forbidden things). ${ }^{55}$

Similarly, the MUI's fatwa on mechanical slaughter of animals provided a legal legitimacy of the then promoted economic development with regard to the provision of animal meat to consumers. ${ }^{56}$ In this regard, the MUI Fatwa Commission considers that the use of machines is merely a form of modernization of knives commonly used in animal slaughter. A knife is only a means of slaughtering animals by not torturing them to the extent possible. Thus, the use of machines is more ihsan to the animals slaughtered. Hence, a machine can be analogous to a knife which is equally a means to facilitate the death of the slaughtered animals in a natural and syar'i manner.

Thus, the transformation of contemporary Islamic legal thought by the MUI in this animal slaughtering fatwa uses the maslahah mursalah approach, although it is not mentioned in the consideration of the fatwa. It correlates to the increase of Islamic legal treasures in Indonesia, as a form

\footnotetext{
${ }^{54}$ See Secretariat of the Indonesian Council of Ulama, Himpunan Fatwa..., xv-xvi.

${ }^{55}$ A. Djazuli, Kaidah-Kaidah Fikih, Jakarta: Kencana, 2006, 76 and 72.

${ }^{56}$ M.Hasbi Umar, Nalar Fiqih Kontemporer..., 166.
} 
of more ihsan behavior in traditional animal slaughter. The MUI's fatwa reinforces the view that Islamic law that is branch is not permanent but it may change with changes in space, time and situation.

The MUI's fatwa allowing genital repair surgery contributes positively to the legal certainty to the transvestites (khunsa) to undergo a genital repair surgery. It determines the identity and the rights of those concerned before the law. The MUI also issued an appeal to support Fatin Sidqiah at X-Factor Indonesia. ${ }^{57}$

The MUI's fatwas showed the increasingly dynamic MUI's attention to the various realities in Indonesian society. The MUI is responsive to issues relevant to the general needs of Muslims. The MUI remains positively attentive to modern values. ${ }^{58}$ It was also shown by the MUI's concern to the financial industry in Indonesia. In 2015, the National Sharia Council of the MUI issued a fatwa number 96/MUI/III/2015 on Islamic Hedging Transactions on exchange rates. This fatwa shows that the MUI as a sharia standard in the financial industry officially recognizes its derivatives to be included as one of Islamic finance instruments in Indonesia. ${ }^{59}$ It has a quite significant effect on the Islamic economic law in Indonesia.

\section{Conclusion}

This paper discusses the fatwas of the Indonesian Council of Ulama (MUI) and its contributions to the development of contemporary Islamic law in Indonesia. The MUI's fatwas use dynamic methodologies in responding to the problems of Islamic law in general, and contemporary

\footnotetext{
${ }^{57}$ See Wahyudi Akmaliah, "When Ulama Support a Pop Singer Fatin Sidqiah and Islamic Pop Culture in Post-Suharto Indonesia," Al-Jami'ah, vol. 52, no. 2 (2014 M/1435 H), 352.

${ }^{58}$ See Mohamad Abdun Nasir, "The Ulama Fatawa and Challenges to Democracy in Contemporary Indonesia," Islam and Christian-Muslim Relations, vol. 25, no. 4 (2014), 502.

59 Yudi Ahmad Faisal, "Islamic Derivatives in Indonesia: a Study on Council of Indonesian Ulama Council (MUI)'s Fatwa on Tahawwut (Hedging)," Islam Ekonomisi Ve Finansi Dergisi, vol. 2 (2016), 36.
} 
Islamic law in Indonesia. In practice, the MUI's fatwas are not only based on al-Qur'an and hadith, but they also use other arguments proportionally, either ijma and qiyas and istihsān, mașlahah mursalah, sadd al-dhari $\vec{a}$ and maqasid al-shari'ah, or opinions of mu'tabar ulamas.

The MUI's fatwas have positive contributions to the transformation of contemporary Islamic law, both related to social, cultural, food, medicine, science and technology areas, as well as worship, and the decisions of the Indonesia Fatwa Commission ulamas regarding masäil dinniyyah asasiyyah wataniyyah, masāil waqi'iyyah mu'aṣirah, masäil qanüniyyah.

During the 1975-2011, the MUI produced 137 fatwas, either in the area of theology and religious sects (14 fatwas), the area of worship (37 fatwas), social and cultural area (51 fatwas), the area of food, medicine, knowledge and technology (35 fatwas), and 50 decisions of the MUI Fatwa Committee in 2003, 2006 and 2009. Thus, for 26 years the MUI produced 137 fatwas and 50 decisions. This contributes positively to the development of contemporary Islamic law in Indonesia. Moreover, MUI is among the elements in contemporary Islamic law in Indonesia. Even the MUI's fatwas have an effect on the development of national law.

\section{Bibliography}

Akmaliah, W., "When Ulama Support a Pop Singer Fatin Sidqiah and Islamic Pop Culture in Post-Suharto Indonesia," Al-Jami“ah, vol. 52, no. 2 (2014 M/1435 H): 351-373.

Anwar, S., "Fatwas, Purification and Dynamization: a Study of Tarjih in Muhammadiyah," Islamic Law and Society, vol. 12, no.1 (2005): 27 44.

Bassiouni, M.C., Sources of Islamic Law, and the Protection of Human Rights in the Islamic Criminal Justice System," in The Islamic Criminal Justice System, New York: Oceana Publications, Inc., 1982: 3-54.

Basya, M. Hilaly, "The Concept of Religious Pluralism in Indonesia: a Study of the MUI's Fatwa and the Debate among Muslim Scholars", 
IJIMS: Indonesian Journal of Islam and Muslim Societies, Volume 8, Number 1, June 2018: 29-56

Indonesian Journal of Islam and Muslim Societies, vol. 1, no. 1 (June 2011): 69-93.

Bik, M.K. Ușül al-Fiqh. Beirut: Dār al-Fikr, 1981.

Al-Dimasyqi, T.A. Kifāyat al-Akhyar fi Hill Gayāt al-Ikhtisār. Vol. 2, Indonesia: Dār Ihyā̄' al-Kutub al-'Arabiyyah, n.d.

Djazuli, A. Kaidah-Kaidah Fikih. Jakarta: Kencana, 2006.

Doi, A.R.I., Shari'ah The Islamic Law. Trans. Basri Iba Asghary and Wadi Masturi, Shari'ah Kodifikasi Hukum Islam. Jakarta: PT Rineka Cipta, 1993.

Faisal, Y.A., "Islamic Derivatives in Indonesia: a Study on Council of Indonesian Ulama Council (MUI)'s Fatwa on Tahawwut (Hedging)," Islam Ekonomisi Ve Finansi Dergisi, vol. 2 (2016): 35-61.

Gillespie, P., "Current Issues in Indonesian Islam: Analysing the 2005 Council of Indonesian Ulama Fatwa No. 7 Opposing Pluralism," Journal of Islamic Studies, Vol. 18, No. 2 (2007): 202-240.

Hadi, S., "The Indonesian Council of Ulama," Indonesia Circle, vol. 18, no. 50 (Nov. 1989): 31-41.

Hasyim, S., "Majelis Ulama Indonesia and Pluralism in Indonesia," Sage Journals: Philosophy EF Social Critism, vol. 41, no. 4-5 (Mey-June 2015): 487-495.

Hasyim, S., "The Council of Indonesian Ulama (Majelis Ulama Indonesia, MUI) and Religious Freedoom,” IRASEC, 12 December (2011): 1-26.

Hosen, N., "Behind the Scenes: Fatwas of Majelis Ulama Indonesia (1975-1998), Journal of Islamic Studies, vol. 15, issue 2 (2004): 147-179. Ibn Nujem. Al-Asybah wa al-Nazair. Egypt: Mu'assasah wa Shurakah, 1968. Ikhwan, M.N., "Ulama, State, and Politics: Majelis Ulama Indonesia After Soeharto," Islamic Law and Society, vol. 12, no. 1 (2005): 45-72. Al-Khallaf, A.W. 'Ilm Us\}ü al-Fiqh. Jakarta: al-Majlis al-A'la al-Indunisi li al-Da'wah al-Islamiyyah, 1972.

Lindsey, Tim et. al., "Monopolising Islam? The Indonesian Ulama Council and State Regulation of the Islamic Economy," Bulletin of Indonesian Economic Studies, vol. 48, no. 2 (2012): 253-274.

Menchik, J., "The Co-Evolution of Sacred And Secular: Islamic Law And Family Planning in Indonesia," South East Asia Research, vol. 22, no. 
3 (2014): 359-378.

Ministry of Religious Affairs of the Republic of Indonesia. Himpunan Fatwa Majelis Ulama Indonesia. Jakarta: Ditjen Bimas Islam dan Penyelenggaraan Haji, 2003: vii-330.

Ministry of Education and Culture of the Republic of Indonesia. Kamus Besar Bahasa Indonesia. Jakarta: Balai Pustaka, 2000.

Mudzhar, M.A., "Pengaruh Faktor Sosial Budaya Terhadap pemikiran Hukum Islam," in Cik Hasan Basri (ed.). Hukum Islam dalam Tatanan

Masyarakat Indonesia. Jakarta: PT Logos Wacana Ilmu, 1998.

Mudzhar, M.A. Fatwas of The Council of Indonesian 'Ulama: A Study of Islamic Legal Thought in Indonesia, 1975-1988. Jakarta: INIS, 1993.

Muhammadiyah Central Board. Himpunan Putusan Majelis Tarjih Muhammadiyah. Yogyakarta: n.p., 1980.

Mulia, S.M. Muslimah Reformis Perempuan Pembaru Keagamaan. Bandung: Mizan, 2005.

Nasir, M.A., "The Ulama Fatawa and Challenges to Democracy in Contemporary Indonesia," Islam and Christian-Muslim Relations, Vol. 25, No. 4 (2014): 489-505.

Nasir, M.A. and Asnawi, "The Majelis Ulama's Fatwa on Abortion in Contemporary Indonesia," The Muslim World, vol. 101, no. 1 (January 2011): 33-52.

Nasution, H. Teologi Islam: Aliran-Aliran Sejarah Analisa Perbandingan. Jakarta: UI Press, 1986.

Nasution, K., "Fatwa Majelis Ulama Indonesia (MUI): On Ahmadiyah," Millah, vol. 7, no. 2 (2008): 1-18.

al-Nawawi, A.Z.Y. Minhaj al-Talibin wa 'Umdat al-Muftin. Semarang: Usaha Keluarga, n.d.

al-Qusyairi, M.B.H. Sahih Muslim. Chapter 2. Beirut: Dār al-Fikr, 1992. Sadr, S.B. Iqtișādunā. Beirut: Dār al-Taā'ruf, 1979.

Al-San'ani. Subul al-Salam, Juz 2. Bandung: Dahlan, n.d.

Secretariat of the Indonesian Council of Ulama. Himpunan Fatwa MUI Sejak 1975. Jakarta: Erlangga, 2011.

al-Syatibi, A.I. Al-Muwāfaqat fi Ușul al-Sharîah, Volume 1, Chapter 2. Beirut: Dār Kutub al-'Ilmiyyah, 1424 H/2003 M. 
IJIMS: Indonesian Journal of Islam and Muslim Societies, Volume 8, Number 1, June 2018: 29-56

Syarifuddin, A. Meretas Kebekuan Ijtihad Isu-Isu Penting Hukum Islam Kontemporer. Jakarta: Ciputat Press, 2002.

Al-Syarqawi. Al-Syarqawi 'ala al-Tahririr, Vol. 2. Singapura: al-Haramain li al-Tibā' ah wa al-Nashr wa al-Tauzi', n.d.

Towana, M.M. Al-Ijtihād: Mādha Hạ̄jatinā Ilaihi fi Hādha al-Aṣr. n.p: Dār al-Kutub al-Hāedithah, 1972.

Umar, M.H. Nalar Fiqih Kontemporer, Jakarta: Gaung Persada Press, 2007: 24-250. 